\title{
EFFECT OF RAIN DROP WASHES ON SOIL FERTILITY IN COTTON PRODUCTION ZONE OF BURKINA FASO
}

\author{
TRAORÉ OUOLA, SOMÉ N. ANTOINE, TRAORÉ KARIM, COULIBALY PANE
}

\begin{abstract}
Crop production in the Sahel is limited by nutrients availability. The study aimed to estimate the contribution of avifauna, crop rotation and trees to soil fertility and crop production improvement. Pot experiment was carried out with soils sampled in Faidherbia albida parklands in cotton production zone of West Burkina Faso. The treatments consisted of two levels of sampling sites (outside and under the crown of Faidherbia albida), three types of previous crop (fallow, maize and sorghum) and two levels of fertilization (normal rain drop and raindrop washes). Results showed that cotton plants height were affected by sampling site and previous crop between 30 and 80 days after sowing. Rain drop washes contained nutrients that can help to improve soil fertility although their nutrients level in the soil is too small to have an impact significant on cotton plant development. No significant difference was observed between factors for the number of nodes and generative branches except for sampling site. Nutrients content in cotton plants was affected by the soil sampling site, the previous crop and the fertilization.
\end{abstract}

Key words: Faidherbia albida, avifauna, rain drop washes, soil fertility, cotton production.

\section{INTRODUCTION}

Agroforestry parklands are common sudanian and sahelian zones of Africa and the Faidherbia albida tree is usually preserved in agricultural systems. Previous studies revealed the positive effect of this leguminous tree on soil fertility and this fact had been linked to the higher concentration of nutrients in soil under Faidherbia albida tree compared to that of soil outside the tree (Depommier et al., 1992; Louppe et al., 1996; Charreau and Vidal, 1965; Seyler, 1993; Olivier et al, 1996). Parklands of Faidherbia albida form an important and diversified avifauna and constitute a microcosm where birds feed and nest (Figure 1A). The birds deliver fecal matter of which some parts are held onto the trees and restituted to soil with rain drop washes. Previous studies on Faidherbia albida tree were focused on its contribution to soil fertility and soil microbial activity under this tree (IRAT, 1965; Campa et al., 1998; Dembélé, 1994; Boffa, 2000). The current study aims to estimate the contribution of rain drop washes to agronomic effects of Faidherbia albida. We hypothesize that nutrients supplied by rain drop when washing Faidherbia albida trees contribute to crop growth and development.

\section{METHODOLOGY}

Study site: Soil was sampled in Faidherbia albida parkland in Dossi village. The village is located at latitude $11^{\circ} 26^{\prime}$ north, longitude $3^{\circ} 24^{\prime}$ west in the sudanian zone with average annual rainfall of $900 \mathrm{~mm}$. The soils depth vary between 0.5 and $3.5 \mathrm{~m}$ (Campa et al., 1998) and have high content of clay and loam. The Faidherbia albida parkland where the soil was sampled had an age of about 40 years. The number of Faidherbia trees $(2,500)$ in the sampling area covered approximately 350 ha of fertile land. The crop rotation system applied on the land is cotton-maize-sorghum.

Soil sampling: Soil samples were collected taking into account the fertility gradient of the land. The sample represented a composite sample of individual samples taken at different distance of the tree. Soil was sampled in the upper 0-20 cm layer. Samples were taken under 
and outside Faidherbia albida trees crown in fields previously cropped with sorghum, maize or fallow. Soils physico-chemical characteristics are summarized in Table 1.

Rain drop washes collection: Plastic pots were hanged on Faidherbia albida trees to collect rain drop from branches and leaves (Figure 1B). Normal rain drops were also collected outside the trees as control rain drop. Rain drop samples were stored at $25^{\circ} \mathrm{C}$ and used to fertilize the pot at the rate of 10.4 liters per pot during the experiment.

Experimental design: Pot experiment was carried out in Farako-Bâ research centre in a greenhouse. The pot experiment started on October 8, 2004 and lasted 5 months. Plastic pots of 15 liters ( $28 \mathrm{~cm}$ upper diameter, $20 \mathrm{~cm}$ bottom diameter and $26.5 \mathrm{~cm}$ of depth) were used. Each pot was filled with $9 \mathrm{~kg}$ of soil. Treatments structure consisted of a combination of: a) two (2) soil sampling sites (under and outside Faidherbia albida tree crown), three (3) types of previous crop (fallow, sorghum and maize) and two (2) types of rain drops (rain drop washes and normal rain drop). Soils samples were taken only outside tree crown in the fallow to represent the control treatment. All the treatments were repeated four times. The pots were randomly arranged in the greenhouse. Five cotton seeds (variety FK37) were planted per pot and thinned to 2 plants after emergence. This variety with a vegetative cycle of 150 days is the one commonly used by cotton growers in the study area where rainfall is above $800 \mathrm{~mm}$.

The trial was implemented at outside temperature and plants were exposed to sun light $7 \mathrm{~h}$ per day. Pots were irrigated every 3 days by watering at $80 \%$ of field capacity to avoid water losses through the pots holes. In order to maintain a good water and air circulation through soil profile in the pots, holes were drilled at the bottom of the pots.

Measurements: The growth and development of cotton were monitored and evaluated by measuring the height of cotton plants at 15, 30, 50, 80, 100 and 120 days after sowing and counting the numbers of nodes and generative branches.

Chemical analysis of soil and plant samples: Plant samples were taken at flowering and maturity and analyzed for their content in total N, P, K and S. Soil samples, rain drop and rain drop washes from Faidherbia albida trees were analyzed. Soil and plants samples were dried under the sun, then in the oven at $70^{\circ} \mathrm{C}$ for 48 hours. The samples were then ground and sieved at $2 \mathrm{~mm}$ prior to laboratory analysis. Analyses were done by Burkina Faso National Office for Soils (BUNASOLS). Samples total carbon (C) was determined using WalkeyBlack method. Total nitrogen $(\mathrm{N})$ was mineralized using Kjedahl digestion and available phosphorus (P) was determined by Bray 1 method and total potassium (K) by photometry. Rain drops nitrate and ammonium were extracted using potassium chloride and measured by colorimetry at $410 \mathrm{~nm}$. Soils and rain drops $\mathrm{pH}$ were measured, using a soil/solution ratio of $1: 2.5$.

\section{Data analysis}

Data collected were computed using Excel and statistical analysis were performed using SAS and XLSTAT at 5\% probability.

\section{RESULTS}

Soils and rain drops chemical characteristics: The area is predominantly clayey with clay and silt content above $60 \%$ irrespective of the previous crop and the sampling location (Table 1). With a silt/clay ratio above 1 , these soils will have tendency to be slippery (Hénin, 1960). Soils organic matter content ( $2 \%$ ) was high compared to the average value of $0.8 \%$ indicated for most soils in Burkina Faso (Piéri, 1989). Soils total $N$ content was around $0.1 \%$ for all the samples, except for those sampled outside the crown of Faidherbia albida and previously cropped with maize or sorghum where total $\mathrm{N}$ content reached $0.2 \%$. Soils were characterized by a low content in available $\mathrm{P}$ even though they showed high content in total $\mathrm{P}$. When compared to soils sampled in the fallow, cultivated soils had higher total $\mathrm{K}$ content. Soils $\mathrm{pH}$ ranged between 6.8 and 7.6 (Table 1). 
Analysis showed that rain drop washes were rich in $\mathrm{P}$ and $\mathrm{N}$ compared to normal rain drop. Rain drop washes had 3.72, 4.50 and $3.22 \mathrm{mg} \mathrm{l}^{-1}$ of phosphates, nitrates and ammonium respectively. Normal rain drop contained mainly nitrates $\left(3.0 \mathrm{mg} \mathrm{l}^{-1}\right)$ and showed on the other hand a low content in phosphates $\left(<0.01 \mathrm{mg}^{-1}\right)$ and ammonium $\left(0.08 \mathrm{mg}^{-1}\right)$ compared to their contents in rain drop washes.

Effect of rain drop washes on cotton plant height: Location of soils samples, the nature of previous crop all affected cotton plant growth but only at three measurement dates: 30,50 and 80 days after sowing (Table 2). However no positive correlation was found between these factors. At 30 and 50 days after sowing (DAS), cotton grown on soils sampled outside the tree crown was taller than cotton grown on soils sampled under the crown. At 80 DAS, a reversal situation was observed with a better development of cotton plants grown on soils sampled under the crown compared to those grown on soils sampled outside the crown. With time, location of soil samples had no significant effect on cotton plant growth. In fact, at 120 DAS, cotton plants had quite the same height, irrespective of soil samples location.

The effects of previous crops showed at 30 and 50 DAS that cotton plants were taller when grown on soils sampled in the fallow than when grown on soils previously cropped with maize or sorghum (Table 2). But, comparable cotton heights were recorded on soils previously cropped with maize or sorghum. At 80 DAS cotton height was taller on soils sampled in maize field than on soils sampled in fallow or in sorghum field. Cotton height was comparable on soils from fallow and sorghum fields (Table 2). At 15, 100 and 120 DAS the previous crop did not affect significantly cotton height.

Cotton plants fertilized with normal rain drop had the same height as those fertilized with rain drop washes, irrespective of the previous crop and soil samples location.

Effect of rain drop washes on cotton plant number of nodes and generative branches: the number of nodes was only affected by the sample location (Table 3 ). In fact, the number of nodes was significantly higher for cotton grown on soil sampled outside the tree crown than for cotton grown on soil sampled under the crown.

The number of nodes according to the previous crop was in the order Fallow $>$ Maize $>$ sorghum. But, no significant difference was found between the previous crops. No significant difference was also observed between the normal rain drop and the rain drop washes. The results in Table 3 show no significant difference between treatments for the number of generative branches for all the studied factors.

Effect of rain drop washes on cotton plant nutrients content: The results on cotton straw nutrient content are presented in Table 4 . The $\% \mathrm{~N}$ content of cotton straw was affected by soil samples site and previous crop. Plant $\% \mathrm{~N}$ content was also related to the number of days after sowing. Plant $\% \mathrm{~N}$ content was always lower at 150 DAS compared to 70 DAS. The $\%$ $\mathrm{N}$ was higher in cotton grown on soil sampled under the crown than in cotton grown on soil sampled outside the crown. Plant \% $\mathrm{N}$ content was higher for cotton grown on soil with sorghum and maize as previous crop than for cotton grown on soil with fallow as previous crop. Cotton $\% \mathrm{~N}$ was comparable when fertilized either with normal rain drop or with rain drop washes (Table 4).

Phosphorus (P) content was not affected by the main effect of soil sampling site, previous crop or fertilization type. However, positive interactions were found between soil sampling site and the number of days after sowing and between the previous crop and the number of days after sowing (Table 5). For cotton grown on soils sampled outside the crown, $\mathrm{P}$ content was higher at 150 DAS compared to 70 DAS while for cotton grown on soils sampled under the tree crown, the opposite situation was observed. The P content of cotton straw increased from 70 DAS to 150 DAS on soils with fallow as previous crop. The opposite situation was observed with maize and sorghum as previous crops (Table 4). 
Results on cotton potassium $(\mathrm{K})$ content were comparable to those found for $\mathrm{P}$ content. No significant difference was found for the main factors (soil sampling site, previous crop and fertilization). Cotton grown on soil sampled outside the crown had $\mathrm{K}$ content which increased from 70 to 150 days after sowing, while soils sampled under the crown, the K content decreased during the same period. Cotton grown on soil with fallow as previous crop had $\mathrm{K}$ content which increased from 70 to 150 days after sowing. The opposite situation was observed with maize and sorghum as previous crops.

The sulphur (S) content of cotton straw content was affected by soil sampling site. S content was higher for cotton grown on soil sampled under the crown than for cotton grown on soil sampled outside the crown. The $\mathrm{S}$ content was also affected by the previous crop. Cotton grown on soil previously cropped with sorghum had higher S content compared to cotton grown on soil previously cropped with maize or fallow. The S content was significantly higher for cotton fertilized with rain drop washes than for cotton fertilized with normal rain drop (Table 4). However, the $\mathrm{S}$ content decreased from 70 to 150 days after sowing in cotton fertilized with normal rain drop while it increased with rain drop washes. A positive interaction was found between the fertilization and the number of days after sowing (Table 5).

\section{DISCUSSION}

At the beginning of the growing cycle of cotton, no significant difference was observed in plant heights. This was due to the fact that young plants were fed on the reserve of cotton embryo and hence no there were differences found between soils sampling site or fertilizers applied. At flowering, a depressive effect of rain drop washes was observed on cotton growth and this could be attributed to the immobilization of $\mathrm{N}$ by soil microorganisms for organic matter decomposition. A lower growth of cotton was observed, compared to cotton grown under field conditions. This can be explained by limited growth conditions in the pots and lower $\mathrm{N}$ supplied by rain drop washes.

The 10.4 liters of rain drop applied per pot during the experiment, supplied 26.8 and $10.7 \mathrm{~kg}$ of $\mathrm{N}$ per ha by rain drop washes and normal rain drop respectively. These quantities of $\mathrm{N}$ are far below the $44 \mathrm{~kg}$ of $\mathrm{N}$ per ha supplied by the fertilization recommended for cotton growing in the area (150 kg of NPKSB, 14-23-14-6-1 and $50 \mathrm{~kg}$ of urea 46\%). Many studies have showed the importance of $\mathrm{N}$ for higher crop yield (Ahn, 1993; Bado et al., 1997; Bado, 2002). The quantity of $N$ supplied by normal rain drop or rain drop washes was not able to cover of cotton plants needs. Even though rain drop washes induced a lower growth of cotton compared to normal rain drop, they contain valuable quantities of $\mathrm{N}$ and $\mathrm{P}$, and therefore represent non negligible source of nutrients for cotton plant fertilization. Dembélé (1994), in an agronomic study showed that rain drop washes collected from Faidherbia albida were more efficient than those collected from Vittelaria paradoxa. However, the author concluded that rain drop washes from Faidherbia albida were efficient for rice production. Normal rain drop as well as rain drop washes did not show significant impact on the number of generative branches. The lower quantity of $\mathrm{N}$ supplied did not allow optimal development of generative organs. These results are in agreement with those reported by Koulibaly (1992) who found that $\mathrm{N}$ application to soil increased the number of cotton bolls. Sampling cotton plant during the flowering i.e. at 70 days after sowing showed higher $\% \mathrm{~N}$ content in soils previously cropped with sorghum because of the soils has original high fertility level as indicated by Koulibaly (1992), Ahn (1993), Dakouo et al. (1995) and Bado (2002). The slightly higher \% $\mathrm{N}$ found in cotton grown in pots fertilized with normal rain drop compared to pots fertilized with rain drop washes at 70 DAS is explained by $\mathrm{N}$ immobilization due to soil microorganisms. The decrease of $\% \mathrm{~N}$ in cotton plant at the end of the growth cycle could be explained by the important translocation of $\mathrm{N}$ to generative organs; as underlined by (Richard 


\section{Journal Of Agriculture and Social Research (JASR) Vol. 6, No.2, 2006}

and Vaez, 1975). N application leads to the expansion of cotton bolls size and volume and an increase in cotton seed weight. A previous study of Koulibaly (1992) showed that cotton plant content in $\mathrm{P}, \mathrm{K}$ and $\mathrm{S}$ remained quite constant during the entire growth of the crop and this was explained by the antagonism between $\mathrm{N}$ and other nutrients uptake such as $\mathrm{P}, \mathrm{K}$ and $\mathrm{S}$. It is therefore noted that the high amount of $\mathrm{N}$ uptake limited the level of $\mathrm{P}$ to a critical level for cotton development (Koulibaly, 1992).

\section{CONCLUSION}

Soil fertility under Faidherbia albida has always been linked on one hand to its capacity to fix atmospheric nitrogen and to release it to soil and on the other hand to animals manure resting under the tree (Campa et al., 1998). The current study showed that rain drop washes contained valuable quantities of $\% \mathrm{~N}$ and $\mathrm{P}$. In spite of these higher $\% \mathrm{~N}$ and $\mathrm{P}$ contents in rain drop washes compared to normal rain drop, the application of this substrate to soil increased soil fertility but no significant influence was observed on cotton growth and development. The study showed positive effects of the previous crop and tree crown on cotton growth. Therefore, it is necessary to maintain agro-forest trees, especially Faidherbia albida in the fields. However, farming and farmers equipment in the agricultural area represent a constraint to the conservation of the species in the fields because young plants are destroyed during land preparation and ploughing. In the light of the current study it is necessary to carry out a study to further underline the depressive effect of rain drop washes on crop growth and development.

\section{REFERENCES}

Ahn P. M. 1993. Tropical soils and fertiliser use. Intermediate tropical - Agriculture series, $252 \mathrm{p}$.

Bado B. V.; Sédogo M. P.; Lompo F. and Bationo A. 1997. Effet à long terme des fumures sur le sol et les rendements du maïs au Burkina Faso. Cahiers Agricultures. Vol. 6 (6), pp 571-575.

Bado B. V. 2002. Rôle des légumineuses sur la fertilité des sols ferrugineux tropicaux des zones guinéennes et soudaniennes du Burkina-Faso. Thèse de Doctorat, $184 \mathrm{p}$.

Boffa J. M. 2000. Les parcs agroforestiers en Afrique Subsaharienne. CIRAF/FAO, 258 p.

Campa C., Grignon C.; Gueye M. and Hamon S. 1998. L'acacia au Sénégal; éditions de l'ORSTOM, $476 \mathrm{p}$.

Charreau C. and Vidal P. 1965. Influence de l'acacia albida sur le sol. Nutrition minérale et rendement des mil pennisetum. L'agronomie tropicale Vol XX, nos 6-7, pp 600-625.

Dakouo D., Koulibaly B.and Hien V. 1995. Agronomie et techniques culturales.

Rapport annuel de la campagne 1993/1994, INERA, 157 p.

Dembélé D. 1994: Ecophysiologie de Faidherbia albida, sa répartition et son effet agronomique; Mémoire d'ingénieur, IDR, Université de Ouagadougou, Burkina Faso, $70 \mathrm{p}$. 
Journal Of Agriculture and Social Research (JASR) Vol. 6, No.2, 2006

Depommier D.; Janodet E.; Olivier R., 1992. Les parcs à Faidherbia albida et leurs influences sur les sols et les cultures à Watinoma, Burkina Faso, $180 \mathrm{p}$.

Hénin S. 1960. Le profil cultural. Principes de physique du sol; Société d'éditions des ingénieurs agricoles, $320 \mathrm{p}$.

Institut de Recherches Agronomiques Tropicales et des cultures vivrières (IRAT). 1965. L'agronomie tropicale. Série agronomie générale. Etudes scientifiques, Service de coopération technique outre mer, $1074 \mathrm{p}$.

Koulibaly B. 1992. Effet de la fertilisation sur l'enracinement et la nutrition minérale du cotonnier. Mémoire d'ingénieur, IDR, Université de Ouagadougou, Burkina Faso, 113 p.

Louppe D., N'Dour B. and Samba S.A.N. 1996. Influence du Faidherbia sur l'arachide et le mil au Sénégal. Méthodologie de mesures et estimation des effets d'arbres émondés avec ou sans parcage d'animaux. In Les parcs à Faidherbia, Cah. Sc. du CIRADForêt, 12 :123-139, CIRAD-ORSTOM-CORAF, Paris.

Olivier R., Depommier D. and Janode E. 1996. Influence de Faidherbia sur le sol et le sorgho. Observations dans le parc de Watinoma au Burkina Faso. In Les parcs à Faidherbia, Cah. Sc. du CIRAD-Forêt, 12 :141-152, CIRAD-ORSTOM-CORAF, Paris, $152 \mathrm{p}$.

Richard L. and Vaez Z. 1975. Etude de la fertilisation azotée du cotonnier en Iran. Coton et fibres tropicales. Vol.xxx. Fasc 3, pp 301-320.

Seyler, R. S. 1993. A systems analysis of status and potential of Acacia albida (Del.) in the north central peanut bassin of Senegal. Ph.D dissertation. Michigan State Univerity, Eart Lansing, USA, 515p. 
Journal Of Agriculture and Social Research (JASR) Vol. 6, No.2, 2006

Table 1: Soils chemical and physical characteristics in the upper $0-20 \mathrm{~cm}$ layer

\begin{tabular}{|c|c|c|c|c|c|}
\hline Previous & Fallow & Sorghum & & Maize & \\
\hline $\begin{array}{l}\text { Soil Sampling } \\
\text { site }\end{array}$ & $\begin{array}{l}\text { outside tree } \\
\text { crown }\end{array}$ & $\begin{array}{l}\text { outside tree } \\
\text { crown }\end{array}$ & $\begin{array}{l}\text { under tree } \\
\text { crown }\end{array}$ & $\begin{array}{l}\text { outside } \\
\text { tree } \\
\text { crown }\end{array}$ & $\begin{array}{l}\text { under tree } \\
\text { crown }\end{array}$ \\
\hline Clay (\%) & 33.3 & 23.5 & 23.5 & 25.5 & 33.3 \\
\hline Silt (\%) & 35.3 & 45.1 & 37.3 & 45.1 & 41.2 \\
\hline Sand $(\%)$ & 31.4 & 31.4 & 39.2 & 29.4 & 25.5 \\
\hline $\begin{array}{l}\text { Organic } \\
\text { matter }(\%)\end{array}$ & 2.10 & 2.60 & 2.10 & 3.10 & 2.10 \\
\hline Total C (\%) & 1.20 & 1.50 & 1.20 & 1.80 & 1.20 \\
\hline Total N (\%) & 0.10 & 0.20 & 0.14 & 0.20 & 0.12 \\
\hline $\begin{array}{l}\text { Total } \quad \mathrm{P} \quad(\mathrm{mg} \\
\left.\mathrm{kg}^{-1}\right)\end{array}$ & 357 & 492 & 499 & 529 & 464 \\
\hline $\begin{array}{l}\text { Available } \\
\left(\mathrm{mg} \mathrm{kg}^{-1}\right)\end{array}$ & 0.4 & 1.6 & 4.3 & $\mathrm{nd}^{*}$ & 2.5 \\
\hline $\begin{array}{l}\text { Total K (mg } \\
\left.\mathrm{kg}^{-1}\right)\end{array}$ & 404 & 3628 & 696 & 4049 & 1348 \\
\hline $\begin{array}{l}\begin{array}{l}\text { Available } \\
\left(\mathrm{mg} \mathrm{kg}^{-1}\right)\end{array} \\
\mathrm{K}\end{array}$ & 87 & 52 & 131 & $\mathrm{nd}$ & 120 \\
\hline pH_ $\mathrm{H}_{2} \mathrm{O}$ & 7.30 & 6.80 & 7.60 & 6.90 & 7.40 \\
\hline
\end{tabular}


Journal Of Agriculture and Social Research (JASR) Vol. 6, No.2, 2006

Table 2: Cotton plant height $(\mathrm{cm})$ as a function of soil sampling place, previous crop and fertilization

\begin{tabular}{llllll}
\multicolumn{2}{l}{ Day after sowing } & & & & \\
\hline 15 & 30 & 50 & 80 & 100 & 120 \\
\hline
\end{tabular}

Soil sampling place

Outside tree crown

Under tree crown

$14.1 \quad 23.0 \quad 30.4$

35.2

43.4

53.6

Probability

12.6

$18.3 \quad 23.6$

38.9

42.1

54.9

L.S.D

0.140

$0.002<0.001$

$0.012 \quad 0.631$

0.699

Significance

2.07

2.82

2.76

5.40

6.76

Previous crop

Fallow $N S^{1}$

$*$

$* *$

* NS NS

Maize

14.1

23.0

30.4

35.2

43.4

53.6

Sorghum

12.6

19.1

24.7

39.2

40.5

52.6

Probability

12.6

$17.4 \quad 22.6$

38.5

43.7

57.2

L.S.D

0.343

$0.006<0.001$

0.041

0.504

0.45

Significance

2.45

3.25

2.94

3.29

6.29

7.81

Fertilization

Normal rain drop NS

$*$

$* *$

$*$

NS

NS

Rain drop washes

$\begin{array}{llllll}13.9 & 20.9 & 27.5 & 39.1 & 43.6 & 54.5 \\ 12.4 & 18.9 & 24.5 & 36.5 & 41.7 & 54.5 \\ 0.13 & 0.22 & 0.09 & 0.06 & 0.45 & 0.99 \\ 1.95 & 3.21 & 3.51 & 2.81 & 5.07 & 6.42 \\ N S & N S & N S & N S & N S & N S\end{array}$

Probability

NS

NS NS NS

${ }^{\mathrm{I}} \mathrm{NS}=$ Not significant at $\mathrm{p}<5 \%, *=$ significant at $\mathrm{p}<5 \%, * *=$ highly significant at $\mathrm{p}<5 \%$ L.S.D $=$ least significant difference 
Journal Of Agriculture and Social Research (JASR) Vol. 6, No.2, 2006

Table 3: Effect of raindrop washes on the number of nodes and generative branches

\begin{tabular}{|c|c|c|}
\hline & $\begin{array}{l}\text { Number of } \\
\text { nodes plant }\end{array}$ & $\begin{array}{l}\begin{array}{l}\text { Number of generative branches } \\
\text { plant }^{-1}\end{array} \\
\end{array}$ \\
\hline \multicolumn{3}{|l|}{ Sampling site } \\
\hline Out of tree crown & 25 & 6 \\
\hline Under tree crown & 22 & 4 \\
\hline Probability & 0.051 & 0.062 \\
\hline L.S.D & 2.34 & 2.20 \\
\hline Significance & $*$ & $N S$ \\
\hline \multicolumn{3}{|l|}{ Previous crop } \\
\hline Fallow & 25 & 6 \\
\hline Maize & 23 & 4 \\
\hline Sorghum & 22 & 4 \\
\hline Probability & 0.139 & 0.180 \\
\hline L.S.D & 2.78 & 2.64 \\
\hline Significance & $N S$ & $N S$ \\
\hline \multicolumn{3}{|l|}{ Fertilization } \\
\hline Normal rain drop & 24 & 5 \\
\hline Rain drop washes & 22 & 4 \\
\hline Probability & 0.255 & 0.148 \\
\hline L.S.D & 2.39 & 2.17 \\
\hline Significance & $N S$ & $N S$ \\
\hline
\end{tabular}


Journal Of Agriculture and Social Research (JASR) Vol. 6, No.2, 2006

Table 4: Effect of rain drop washes on cotton plant nutrients content

\begin{tabular}{|c|c|c|c|c|c|c|c|c|}
\hline & \multicolumn{2}{|c|}{$\mathbf{N}\left(\% \mathrm{DM}^{*}\right)$} & \multicolumn{2}{|c|}{$\mathbf{P}(\% \mathrm{DM})$} & \multicolumn{2}{|c|}{$\mathbf{K}(\% \mathrm{DM})$} & \multicolumn{2}{|c|}{$\mathrm{S}(\% \mathrm{DM})$} \\
\hline Day after sowing & 70 & 150 & 70 & 150 & 70 & 150 & 70 & 150 \\
\hline $\begin{array}{l}\text { Soils } \\
\text { place }\end{array}$ & & & & 0.75 & 2.35 & 3.65 & 0.45 & \\
\hline Out the crown & 2.35 & 0.95 & 0.30 & 0.45 & 3.46 & 2.23 & 0.66 & 0.42 \\
\hline Under the crown & 4.11 & 2.30 & 0.82 & & & & & 0.62 \\
\hline Previous crop & & & & & & & & \\
\hline Fallow & 2.35 & 0.95 & 0.30 & 0.75 & 2.35 & 3.65 & 0.45 & 0.42 \\
\hline Maize & 3.25 & 2.05 & 1.15 & 0.42 & 4.28 & 2.35 & 0.60 & 0.50 \\
\hline Sorghum & 4.97 & 2.55 & 0.50 & 0.47 & 2.65 & 2.10 & 0.72 & 0.75 \\
\hline Fertilization & & & & & & & & \\
\hline Normal rain drop & 3.88 & 1.75 & 0.63 & 0.62 & 3.02 & 3.13 & 0.58 & 0.35 \\
\hline Rain drop washes & 3.17 & 1.95 & 0.67 & 0.48 & 3.17 & 2.27 & 0.60 & 0.77 \\
\hline
\end{tabular}

$\mathrm{DM}^{*}$ : Dry matter 
Journal Of Agriculture and Social Research (JASR) Vol. 6, No.2, 2006

A

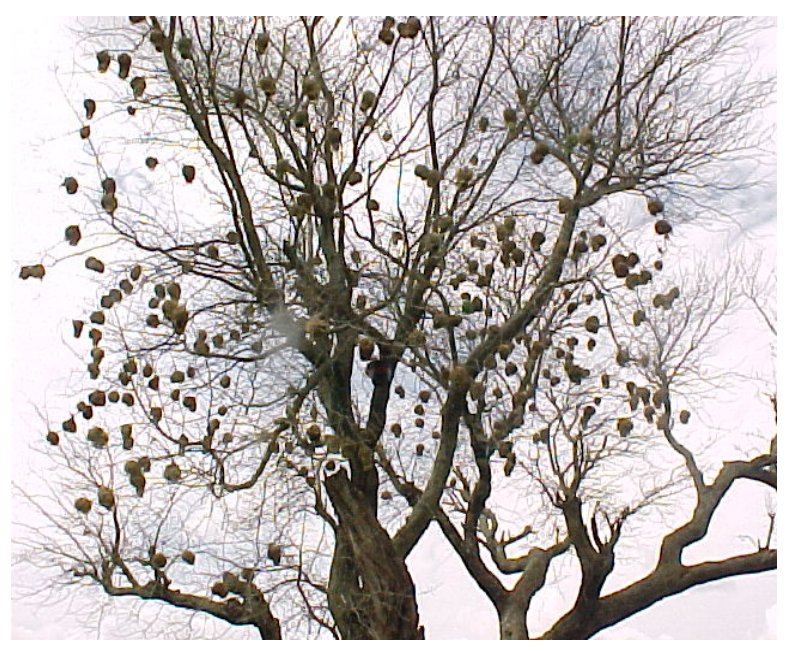

B

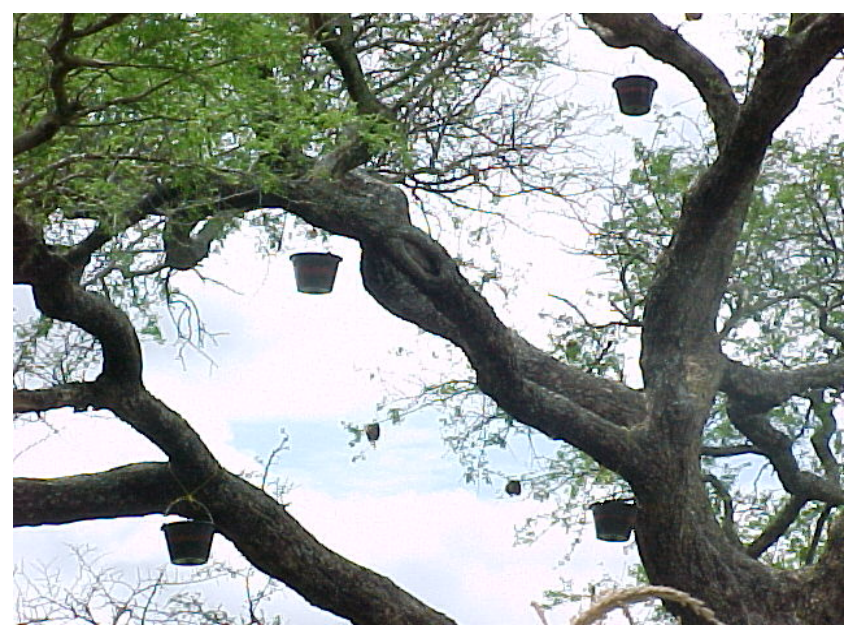

Figure 1: Faidherbia albida tree occupied by avifauna nests (A) and rain drop washes collection (B) 
Journal Of Agriculture and Social Research (JASR) Vol. 6, No.2, 2006 
Journal Of Agriculture and Social Research (JASR) Vol. 6, No.2, 2006

Table 5: Statistics on the effect rain drop washes on cotton plant nutrients content

\begin{tabular}{|c|c|c|c|c|}
\hline & $\mathbf{N}(\%)$ & $\mathbf{P}(\%)$ & K (\%) & S (\%) \\
\hline Day after sowing & 150 & 150 & 150 & 150 \\
\hline $\begin{array}{l}\text { Soils sampling place } \\
\text { Day after sowing } \\
\text { Sampling place } \mathrm{x} \text { day }\end{array}$ & $\begin{array}{l}\mathrm{p}<.001, \mathrm{LSD}=0.803 \\
\mathrm{p}<.001, \mathrm{LSD}=0.757 \\
\mathrm{P}=0.598, \mathrm{LSD}=0.927\end{array}$ & $\begin{array}{l}\mathrm{P}=0.435, \mathrm{LSD}=0.294 \\
\mathrm{P}=0.461, \mathrm{LSD}=0.278 \\
\mathrm{P}=0.008, \mathrm{LSD}=0.340\end{array}$ & $\begin{array}{l}\mathrm{P}=0.726, \mathrm{LSD}=0.91 \\
\mathrm{P}=0.356, \mathrm{LSD}=0.865 \\
\mathrm{P}=0.009, \mathrm{LSD}=1.059\end{array}$ & $\begin{array}{l}\mathrm{P}=0.043, \mathrm{LSD}=0.199 \\
\mathrm{P}=0.715, \mathrm{LSD}=0.188 \\
\mathrm{P}=0.948, \mathrm{LSD}=0.229\end{array}$ \\
\hline $\begin{array}{l}\text { Previous crop } \\
\text { Day after sowing } \\
\text { Previous crop x day }\end{array}$ & $\begin{array}{l}\mathrm{p}<.001, \mathrm{LSD}=0.757 \\
\mathrm{p}<.001, \mathrm{LSD}=0.618 \\
\mathrm{P}=0.218, \mathrm{LSD}=1.071\end{array}$ & $\begin{array}{l}\mathrm{P}=0.074, \mathrm{LSD}=0.279 \\
\mathrm{P}=0.370, \mathrm{LSD}=0.228 \\
\mathrm{P}=0.001, \mathrm{LSD}=0.395\end{array}$ & $\begin{array}{l}\mathrm{P}=0.145, \mathrm{LSD}=0.966 \\
\mathrm{P}=0.310, \mathrm{LSD}=0.788 \\
\mathrm{P}=0.009, \mathrm{LSD}=1.365\end{array}$ & $\begin{array}{l}\mathrm{P}=0.035, \mathrm{LSD}=0.222 \\
\mathrm{P}=0.706, \mathrm{LSD}=0.182 \\
\mathrm{P}=0.841, \mathrm{LSD}=0.316\end{array}$ \\
\hline $\begin{array}{l}\text { Fertilization } \\
\text { Day after sowing } \\
\text { Fertilization } \mathrm{x} \text { day }\end{array}$ & $\begin{array}{l}\mathrm{P}=0.594, \mathrm{LSD}=0.995 \\
\mathrm{P}=0.002, \mathrm{LSD}=0.995 \\
\mathrm{P}=0.348, \mathrm{LSD}=1.407\end{array}$ & $\begin{array}{l}\mathrm{P}=0.757, \mathrm{LSD}=0.332 \\
\mathrm{P}=0.537, \mathrm{LSD}=0.332 \\
\mathrm{P}=0.607, \mathrm{LSD}=0.407\end{array}$ & $\begin{array}{l}\mathrm{P}=0.459, \mathrm{LSD}=0.990 \\
\mathrm{P}=0.419, \mathrm{LSD}=0.990 \\
\mathrm{P}=0.297, \mathrm{LSD}=1.400\end{array}$ & $\begin{array}{l}\mathrm{P}=0.009, \mathrm{LSD}=0.156 \\
\mathrm{P}=0.662, \mathrm{LSD}=0.156 \\
\mathrm{P}=0.015, \mathrm{LSD}=0.221\end{array}$ \\
\hline
\end{tabular}

L.S.D = least significant difference 